\title{
Role of Tristetraprolin in the Resolution of Inflammation
}

\author{
Peter Rappl 1, Bernhard Brüne 1,2,3,4 (D) and Tobias Schmid 1,*(D) \\ 1 Institute of Biochemistry I, Faculty of Medicine, Goethe-University Frankfurt, 60590 Frankfurt, Germany; \\ rappl@biochem.uni-frankfurt.de (P.R.); B.Bruene@biochem.uni-frankfurt.de (B.B.) \\ 2 German Cancer Consortium (DKTK), Partner Site Frankfurt, 60590 Frankfurt, Germany \\ 3 Frankfurt Cancer Institute, Goethe-University Frankfurt, 60596 Frankfurt, Germany \\ 4 Project Group Translational Medicine and Pharmacology TMP, Fraunhofer Institute for Molecular and \\ Applied Ecology, 60596 Frankfurt, Germany \\ * Correspondence: t.schmid@biochem.uni-frankfurt.de
}

check for

updates

Citation: Rappl, P.; Brüne, B.;

Schmid, T. Role of Tristetraprolin in

the Resolution of Inflammation.

Biology 2021, 10, 66. https://doi.org/

10.3390/biology10010066

Received: 22 December 2020

Accepted: 16 January 2021

Published: 19 January 2021

Publisher's Note: MDPI stays neutral with regard to jurisdictional claims in published maps and institutional affiliations.

Copyright: (c) 2021 by the authors. Licensee MDPI, Basel, Switzerland. This article is an open access article distributed under the terms and conditions of the Creative Commons Attribution (CC BY) license (https:// creativecommons.org/licenses/by/ $4.0 /)$.
Simple Summary: Chronic inflammatory diseases account for up to $60 \%$ of deaths worldwide and, thus, are considered a great threat for human health by the World Health Organization. Nevertheless, acute inflammatory reactions are an integral part of the host defense against invading pathogens or injuries. To avoid excessive damage due to the persistence of a highly reactive environment, inflammations need to resolve in a coordinate and timely manner, ensuring for the immunological normalization of the affected tissues. Since post-transcriptional regulatory mechanisms are essential for effective resolution, the present review discusses the key role of the RNA-binding and post-transcriptional regulatory protein tristetraprolin in establishing resolution of inflammation.

\begin{abstract}
Inflammation is a crucial part of immune responses towards invading pathogens or tissue damage. While inflammatory reactions are aimed at removing the triggering stimulus, it is important that these processes are terminated in a coordinate manner to prevent excessive tissue damage due to the highly reactive inflammatory environment. Initiation of inflammatory responses was proposed to be regulated predominantly at a transcriptional level, whereas post-transcriptional modes of regulation appear to be crucial for resolution of inflammation. The RNA-binding protein tristetraprolin (TTP) interacts with AU-rich elements in the $3^{\prime}$ untranslated region of mRNAs, recruits deadenylase complexes and thereby facilitates degradation of its targets. As TTP regulates the mRNA stability of numerous inflammatory mediators, it was put forward as a crucial post-transcriptional regulator of inflammation. Here, we summarize the current understanding of the function of TTP with a specific focus on its role in adding to resolution of inflammation.
\end{abstract}

Keywords: RNA-binding protein; AU-rich element; post-transcriptional regulation; mRNA stability

\section{Introduction}

Effective immune responses towards pathogens or injury are characterized by acute inflammations aimed at eliminating the inciting stimulus. To prevent inefficient removal of the threat but also excessive damage to the host, inflammatory processes must be tightly controlled. Thus, in addition to transcriptional regulation contributing to de novo expression of inflammatory mediators, a strict post-transcriptional regulatory program ensures the timely and quick adaptation of the responses to rapidly changing environmental cues in the progress of inflammation [1,2].

\section{Inflammation}

\subsection{The Course of Inflammation}

Inflammatory reactions are important to combat invading pathogens [3,4]. Nevertheless, to prevent local tissue damage due to the sustained production of highly reactive inflammatory mediators, including reactive oxygen species and nitric oxide [5], 
and to reduce the risk of systemic effects, inflammatory responses need to be resolved in a timely manner [6]. In line, the course of acute inflammations is tightly regulated and follows a common pattern (Figure 1). Bacterial or viral pathogens, i.e., pathogen-associated patterns (PAMPs), are commonly detected by tissue-resident macrophages, which constitute the first line of defense, via so-called pattern-recognition receptors (PRRs) $[7,8]$. Similarly, tissue damage elicits an inflammatory response in local phagocytes by activating PRRs via damage-associated molecular patterns (DAMPs), such as intracellular components released upon necrotic cell death $[9,10]$. The most prominent family of PRRs are the Toll-like receptors (TLRs). They activate intracellular signaling cascades including kinases (e.g., mitogen-activated protein kinases (MAPKs)) and transcription factors (e.g., nuclear factor $\mathrm{K} B(\mathrm{NF} \mathrm{B})$ ) to coordinate the inflammatory responses [11,12]. Upon activation, resident macrophages rapidly recruit neutrophils, which spear-head the pro-inflammatory responses [13-15]. Neutrophils are closely followed by infiltrating monocytes, which subsequently differentiate into macrophages within the respective tissue [16]. In line with their versatile regulatory functions, macrophages are a highly plastic cell type [17]. Upon activation, they present an inflammatory, classically activated phenotype, characterized by production of pro-inflammatory cytokines, such tumor necrosis factor (TNF), interleukin 6 (IL6), or IL8 [18,19]. During the progression of the inflammatory process and triggered by the phagocytosis of the rapidly dying neutrophils, they take on an alternatively activated phenotype producing anti-inflammatory mediators, e.g., IL10 [20-23]. The last phase of an acute, transient inflammation is aimed at resolving the inflammatory environment, both pro- and anti-inflammatory components, and reestablishing cellular and humoral homeostasis at the site of inflammation [24,25]. Importantly, while resolution was considered a rather passive event for a long time, it is now widely accepted to be a highly regulated, complex process, which is initiated already early on during the course of inflammation $[26,27]$. In fact, successful resolution is not the end of this dynamic process, but recent reports indicate that it is followed by a prolonged post-resolution phase characterized by an altered, immune suppressive environment [28,29].

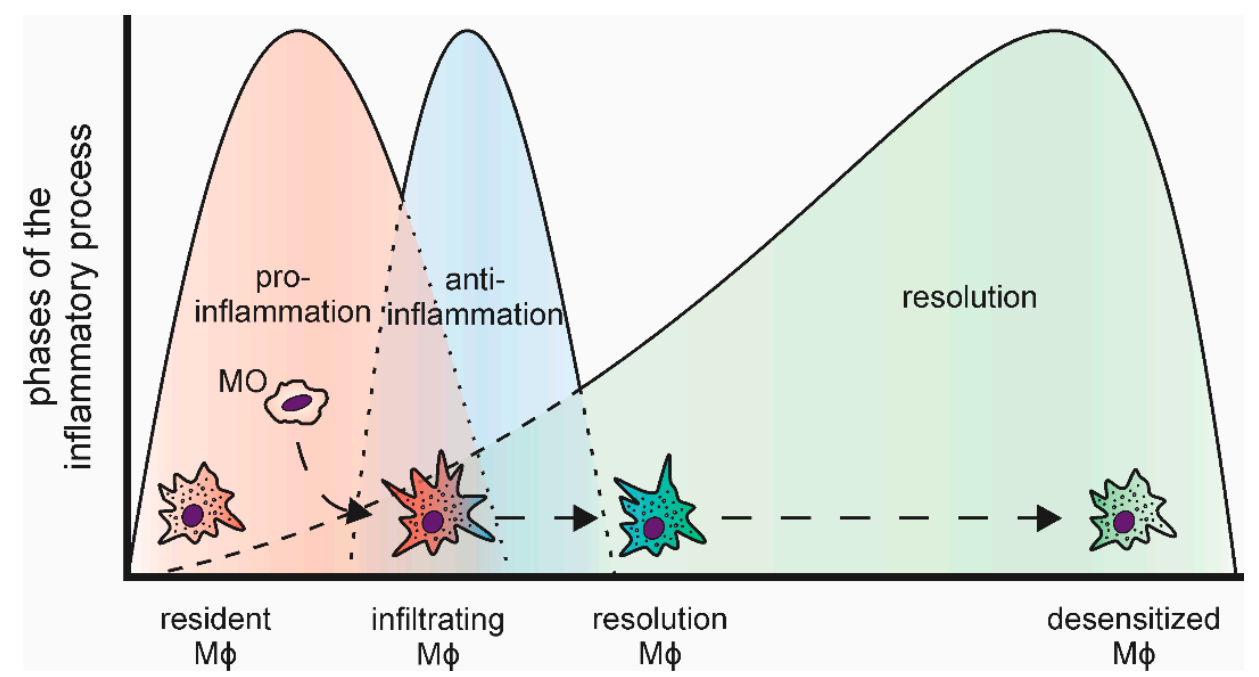

Figure 1. Distinct phases of an acute, transient inflammatory process and the respective macrophage subtypes (MO: monocyte; Mф: macrophage).

As indicated above, macrophages fulfill a central role in the execution of inflammatory responses. Interestingly though, macrophage populations change massively during inflammation, i.e., the original tissue resident macrophage population of mesodermal origin is rapidly reduced upon influx of neutrophils, both by cell death and emigration [30], and macrophages differentiating from infiltrating monocytes emerge to replenish the resident macrophage pool [31,32]. 


\subsection{Post-Transcriptional Regulation in Inflammation}

While typical transcriptional changes characterize inflammatory responses brought about, e.g., by transcription factors of the STAT and NFKB families [33,34], expression of many inflammatory mediators is subject to tight post-transcriptional control as well. The latter coordinates the emergence and, even more importantly, the timely termination of the production of certain factors $[33,35]$. The specificity of such mechanisms is achieved by intricate regulatory principles encoded within the sequence of individual mRNAs and by a wealth of trans-acting factors such as non-coding RNA species [36] and RNA-binding proteins (RBPs) $[37,38]$. For example, roquin- 1 and regnase- 1 (monocyte chemotactic protein-induced protein 1 (MCPIP1)) have been shown to be induced in macrophages by inflammatory stimuli and in turn regulate inflammatory responses in a coordinate manner [39-41]. Specifically, regnase-1 is an early response gene, and via its endonuclease function, cleaves actively translated inflammatory target mRNAs during the early phase of inflammation to limit the extent of the inflammatory reactions [42-44]. In line, mice deficient for regnase- 1 develop spontaneous inflammatory syndromes, likely due to uncontrolled immune responses to external pathogens as these could be these could be attenuated by antibiotics treatment [45]. In contrast, roquin-1 was shown to degrade translationally inactive mRNAs stored in stress granules or processing bodies, thereby tuning inflammatory gene expression during later phases to prevent chronification of inflammatory process $[46,47]$. Interestingly, failure to localize to processing bodies due to mutational inactivation of the respective domain provoked a hyperinflammatory phenotype in mice and was even described for a human case [48]. Of note, recent studies further identified a huge number of unconventional RBPs, many of which were primarily characterized as metabolic enzymes (e.g., glyceraldehyde-3-phosphate dehydrogenase) carrying-out additional "moonlighting" functions [49,50], stressing the tight interplay between metabolism and post-transcriptional regulation. Considering the elevated energetic demand in inflammatory settings [51,52], it can be speculated that some of the not yet characterized RBPs might be involved in the post-transcriptional control of inflammatory mediators as well.

Amongst the classical RBPs, tristetraprolin (TTP) emerged as one of the most prominent post-transcriptional regulators of immune functions. Here, we want to provide a brief update of the role of TTP during the course of inflammation, specifically focusing on its contribution to an effective resolution phase.

\section{Tristetraprolin}

\subsection{TTP Structure and Function}

TTP (or ZFP36) was first described in 1991 [53] and belongs to a highly conserved family of zinc-finger proteins with RNA-binding properties [54]. In addition to domains facilitating its nuclear-cytoplasmic shuttling, TTP contains a C-terminal NOT1 binding domain and, alike other members of the TTP family, two tandem CCCH-type zinc-finger domain structures. The activity of TTP is pre-dominantly regulated by post-translational modifications, affecting stability, localization, and DNA binding properties of TTP [55-58]. The phosphorylation of TTP by p38-MAPK-activated protein kinase 2 (MK2) emerged as the major regulator of TTP activity [59,60]. Specifically, MK2 phosphorylates TTP at two serine residues (mouse: S52 and S178; human: S60 and S186), thereby creating binding sites for the chaperone 14-3-3, which prevents localization of TTP to stress granules, thereby inhibiting the mRNA destabilizing activity of TTP [61,62]. Activation of TTP can be achieved by various phosphatases [63], while dual-specificity phosphatase 1 (DUSP1) was shown to prevent TTP inactivation by inhibiting p38-MAPK $[64,65]$, protein phosphatase 2A (PP2A) dephosphorylates and thereby prevents interaction with 14-3-3 [66,67]. As a side note, Dusp1 itself is a target of TTP-mediated destabilization. Consequently, inactivation of TTP by p38-MAPK at the same time enhances expression of the p38-MAPK inhibitor DUSP1, providing a negative feedback mechanism to ensure tight and rapid regulation of inactivation and reactivation of TTP [68] (Figure 2a). 
a

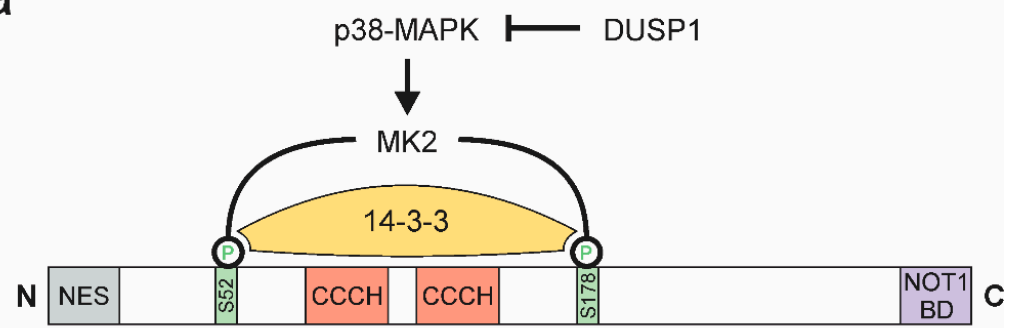

b

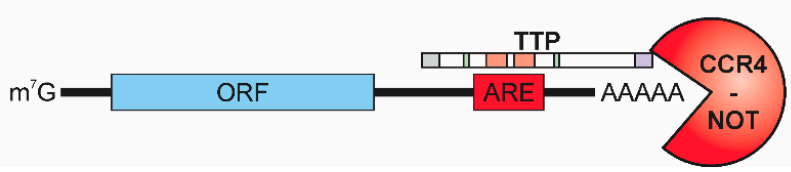

Figure 2. Tristetraprolin (TTP) protein structure, activity regulation, and function. (a) p38-MAPK activates MK2, which phosphorylates TTP at serines 52 and 178 (mouse), which allows for binding of 14-3-3 and inactivation of TTP. DUSP 1 inhibits p38-MAPK. (NES: nuclear export signal; NOT1 BD: NOT1 binding domain) (b) TTP interacts with adenosine and uridine (AU)-rich elements (AREs) in the $3^{\prime}$ untranslated region of target mRNAs and recruits the CCR4-NOT deadenylation complex, facilitating rapid degradation of the target mRNA. (ORF: open reading frame).

The CCCH domains constitute the RNA-interaction interphase of TTP [41]. They allow TTP to specifically interact with adenosine and uridine (AU)-rich elements (AREs) [69], which are commonly found within $3^{\prime}$ untranslated regions ( $3^{\prime}$ UTRs) of mRNAs and have been described as important RNA stability regulatory platforms for a broad group of ARE-binding proteins [70,71]. While the ARE-binding properties of TTP have been described early after its discovery [72,73], recently, global interaction mapping studies suggested preferential binding of TTP to nonameric UUAUUUAUU motifs or heptameric UAUUUAU motifs [74-76]. Upon binding to its target mRNAs, TTP recruits the CCR4-NOT deadenylation complex via its C-terminal NOT1-binding domain [77-80], thereby allowing for deadenylation and subsequent $3^{\prime}-5^{\prime}$ exosomal degradation of the respective target mRNA [81] (Figure 2b).

In addition to the mRNA destabilizing properties, TTP was also shown to inhibit the translation of mRNAs [82-84]. The finding that TTP is able to regulate its targets at various post-transcriptional levels underscores the notion that such regulatory and redundant principles are required to rapidly and efficiently regulate the timely expression of specific targets $[75,85]$.

\subsection{TTP in the Resolution of Inflammation}

TTP activity is tightly regulated during the course of inflammation via the inhibitory activity of p38-MAPK [59], but also by autoregulation [86]. To assess how TTP contributes to the regulation of inflammation, various groups have used RNomics approaches to identify mRNAs both directly bound and regulated by TTP in bone marrow-derived macrophages (BMDM) in response to inflammatory stimulation with LPS $[37,74,75]$. In the following, we will discuss the combined findings to provide an overview of TTP targets from the onset ( $1 \mathrm{~h}$ LPS) via the peak ( $3 \mathrm{~h}$ LPS) to the early resolution of inflammation (6 h LPS).

Since TTP is inactivated early during inflammatory simulation, Tiedje et al. determined TTP targets under these conditions using an individual-nucleotide resolution crosslinking and immunoprecipitation (iCLIP) approach using TTP-knockout (TTP-k/o) BMDMs overexpressing either wildtype TTP (TTP-wt) or a phosphorylation-site (S52/178A) TTP mutant (TTP-AA), which is inactivation-resistant [37]. Using this approach, they identified 4106 mRNAs to be bound by TTP within their $3^{\prime}$ UTRs. Interestingly, only for a small proportion of these TTP-interacting mRNAs enhanced LPS-induced expression was sensitive 
to expression of the constitutively active TTP-AA. Specifically, 8 mRNAs showed higher expression in TTP-wt as compared to TTP-AA expressing BMDMs after $1 \mathrm{~h}$ LPS treatment (Table 1; left columns). Amongst these, immediate early response 3 (Ier3), a feedback inhibitor of NFKB signaling [87], appeared to benefit most from TTP inactivation in TTP-wt cells. In line, the authors identify altered NFKB activation signatures in TTP-AA expressing macrophages. Similarly, urokinase-type plasminogen activator (Plau) mRNA appeared to be stabilized when TTP was inactivated in TTP-wt cells. PLAU was previously shown to act anti-inflammatory by suppressing fibrin-deposition induced inflammation [88] and inflammatory osteoclastogenesis [89]. These findings suggest that inactivation of TTP, rather than providing an additional boost to inflammatory targets, post-transcriptionally derepresses feedback inhibitors of inflammation and anti-inflammatory targets, thereby setting the stage for successful resolution already very early on during the inflammatory process (Figure 1). In line, high levels of active TTP at this stage of inflammation have been shown to enhance the stability of certain ARE-containing transcripts, such as Tnf and Cxcl2, supporting the concept that a proper resolution phase requires an intact inflammatory phase, also at the level of TTP activity regulation [90].

Table 1. Differential expression of TTP-bound mRNAs during different phases of inflammation.

\begin{tabular}{|c|c|c|c|c|c|}
\hline \multicolumn{2}{|c|}{ Inflammatory Onset ${ }^{1}$} & \multicolumn{2}{|c|}{ Peak Inflammation $^{2}$} & \multicolumn{2}{|r|}{ Early Resolution ${ }^{3}$} \\
\hline Gene ID & $\begin{array}{c}\log 2 \mathrm{FC} \\
\text { (TTP-wt vs. TTP-AA) }\end{array}$ & Gene ID & $\begin{array}{c}\Delta \log 2 \mathrm{FC} \\
\text { (TTP-ko/ctr vs. TTP-wt/ctr) }\end{array}$ & Gene ID & $\begin{array}{c}\Delta \log 2 \mathrm{FC} \\
\text { (TTP-ko/ctr vs. TTP-wt/ctr) }\end{array}$ \\
\hline Ier3 & 0.91 & Gdf15 & 1.73 & Cxcl1 & 3.86 \\
\hline Plau & 0.57 & Eno2 & 1.26 & Cxcl2 & 3.34 \\
\hline$L p l$ & 0.56 & Mllt11 & 1.23 & Eno2 & 2.07 \\
\hline$M d m 2$ & 0.46 & Cxcl1 & 1.00 & Mllt11 & 1.73 \\
\hline Mat2a & 0.44 & $\mathrm{Cxcl} 2$ & 0.94 & Ccl3 & 1.46 \\
\hline Plek & 0.36 & Rusc2 & 0.67 & 1110 & 1.39 \\
\hline Canx & 0.35 & & 0.45 & $\operatorname{Tnf}$ & 1.36 \\
\hline \multirow[t]{13}{*}{ Actr2 } & 0.26 & Zeb2 & 0.26 & Rusc2 & 0.87 \\
\hline & & Il10 & 0.25 & Il27 & 0.74 \\
\hline & & $\operatorname{Prdx1}$ & 0.20 & Notch1 & 0.50 \\
\hline & & Notch1 & 0.14 & Maf & 0.35 \\
\hline & & Sfmbt1 & 0.13 & $\mathrm{Ccl}$ & 0.35 \\
\hline & & Cish & 0.03 & Fam $49 b$ & 0.33 \\
\hline & & Cflar & 0.02 & $C d k n 1 a$ & 0.28 \\
\hline & & & & Zeb2 & 0.28 \\
\hline & & & & & 0.23 \\
\hline & & & & Il10ra & 0.21 \\
\hline & & & & & 0.05 \\
\hline & & & & Ccl2 & 0.05 \\
\hline & & & & Aff1 & 0.02 \\
\hline
\end{tabular}

Green: feedback regulators; red: inflammatory TTP targets; blue: anti-inflammatory TTP targets. ${ }^{1}$ Top $503^{\prime} \mathrm{UTR}$-bound TTP targets, filtered for targets with higher induction of mRNA expression in TTP-wt as compared to inactive TTP-AA expressing BMDM after $1 \mathrm{~h}$ LPS (from [37]). ${ }^{2}$ Top 50 3'UTR-bound TTP targets, filtered for targets with higher induction of mRNA expression in TTP-k/o as compared to TTP-wt BMDM after $3 \mathrm{~h}$ LPS (from [74]). ${ }^{3}$ Top $503^{\prime}$ UTR-bound TTP targets, filtered for targets with higher induction of mRNA expression in TTP-k/o as compared to TTP-wt BMDM after $6 \mathrm{~h}$ LPS (from [74]).

While TTP is inactivated during the onset of inflammation, it becomes gradually reactivated during the progression of inflammation by autoregulatory feedback loops. Specifically, as TTP destabilizes its own mRNA, inactivation of TTP allows for enhanced expression of TTP [86]. At the same time, the TTP target DUSP1 increases, which inhibits p38-MAPK, thereby allowing for activation of TTP [68]. Thus, the TTP-interacting targets determined by Sedlyarov and colleagues using a photoactivatable- (PAR-) iCLIP approach for TTP in BMDMs after 3 and $6 \mathrm{~h}$ of LPS served as indicators for later stages of the inflammatory course [74]. In line with the predicted TTP activation pattern, the number of TTP targets responsive to changes in the availability of TTP (i.e., TTP-wt vs. TTP-k/o) increased. 
In addition to Ier3, which appeared to be a highly regulated TTP target throughout the course of inflammation, Cxcl1 and Cxcl2 showed a strong increase in expression in TTP-deficient (TTP-k/o) BMDM at peak inflammation ( $3 \mathrm{~h}$ LPS; Table 1, middle columns). Cxcl1 and Cxcl2 are well-established TTP targets [91,92], both being important chemokines contributing to early stage neutrophil recruitment [93]. The observation that the reduction in neutrophil-attracting chemokines in the presence of active TTP in TTP-wt cells even precedes the impact of TTP on early response pro-inflammatory cytokines, such as Tnf, provides further evidence for a tightly regulated, TTP-controlled resolution program, which is initiated already during the onset of inflammation [94]. The well-known antiinflammatory TTP target Il10 [95-97] appeared to be downregulated by TTP also already during the presumed pro-inflammatory phase.

Moving on to early resolution of inflammation (6 h LPS), not only the number of mRNAs bound and regulated by TTP but also the degree of TTP-dependent regulation massively increased (Table 1, right columns). In addition to the neutrophil-targeting chemokines Cxcl1 and Cxcl2, further chemokines including Ccl2 [98], Ccl3 [99], and Ccl4 [100] were down-regulated by TTP at the start of the resolution phase. While CCL3 attracts and activates neutrophils and also monocytes and macrophages, CCL2 rather recruits monocytes, memory $\mathrm{T}$ cells, and dendritic cells, while CCL4 primarily attracts natural killer cells and monocytes [101,102]. Thus, TTP appears to initiate the normalization of the cellular environment at the site of inflammation very early during the resolution. Of note, while Tnf was established as a TTP target early on [72,98,103-105], it only emerged as TTP-bound and -responsive target after $6 \mathrm{~h}$ of LPS in the present studies, while it was not regulated by TTP at 1 or $3 \mathrm{~h}$ of LPS. This is in line with previous reports showing that Tnf accumulates maximally in BMDM at $3 \mathrm{~h}$ of LPS declining only thereafter [1,75].

Corroborating the importance of TTP for the onset of resolution, Joe et al. recently showed that CD38 induces TTP expression already during early inflammation via its products nicotinic acid adenine dinucleotide phosphate (NAADP) and cyclic ADP ribose (cADPR). As part of a feedback loop, increasing TTP levels destabilize $C d 38$, which results in the accumulation of nicotinamide adenine dinucleotide $\left(\mathrm{NAD}^{+}\right)$, the pre-cursor of the abovementioned second messengers. Elevated $\mathrm{NAD}^{+}$concentrations then activate SIRT1, which enhances TTP activity by deacetylation during the onset of resolution. In addition to the regulation of cytokines, TTP inhibits the expression of the mTOR-activator RHEB, thereby inducing autophagolysosome formation, which is crucial for bacterial clearance [106]. In contrast, deletion of TTP was recently shown to protect neutrophils from apoptosis, which enhanced their anti-microbial activity [107].

Taken together, TTP emerges as a regulator of resolution, by coordinating the regulation of the early phases of resolution, which are initiated already immediately after inflammatory stimulation (Figure 3).

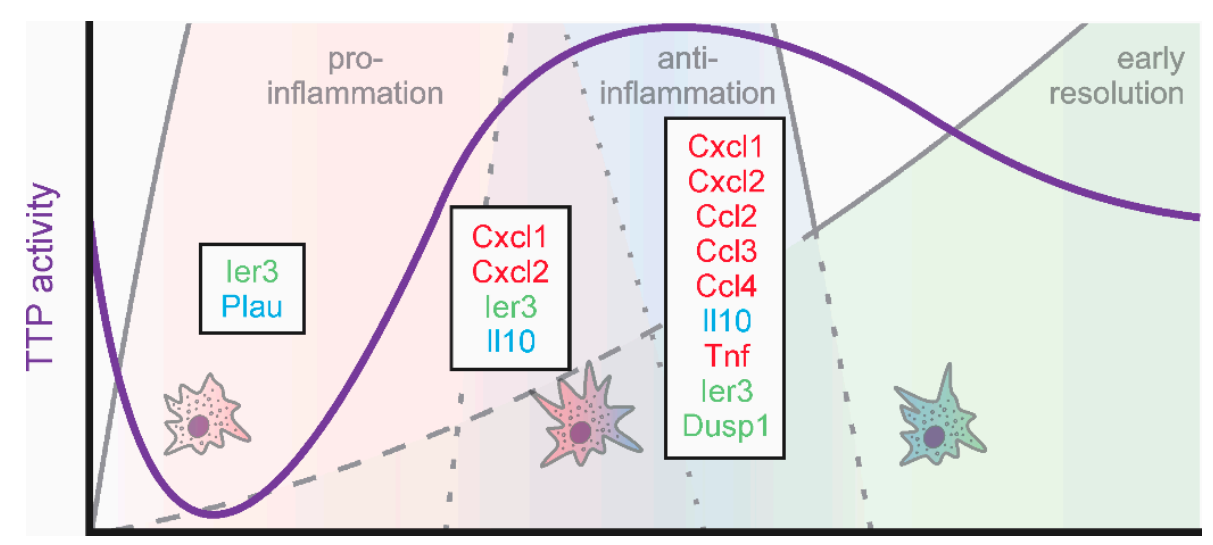

Figure 3. TTP activity (violet) and targets (green: feedback regulators; red: inflammatory; blue: antiinflammatory) in macrophages during the early phases of inflammation. 
Nevertheless, while in vitro studies provide important mechanistic and regulatory insights regarding the function of TTP, various mouse models have been generated to study the impact of TTP in vivo. In line with the inflammation-regulatory function of TTP, mice with a global TTP-knockout develop a severe inflammatory disease phenotype soon after birth $[108,109]$. In contrast, mice with a myeloid-specific depletion of TTP exhibit only a minimal spontaneous phenotype but appear hypersensitive against inflammatory challenge [110]. Furthermore, mice expressing only the non-phosphorylatable, constitutively active TTP-AA mutant showed a strongly attenuated inflammatory response to LPS [111]. Nevertheless, these mice were also not able to develop a desired inflammatory immune response against infections with Salmonella typhimurium [112], indicating that tunable TTP is crucial for the regulation of appropriate immune responses. Interestingly, deletion of the AREs within the TTP $3^{\prime}$ UTR sufficed to increase the expression of TTP and protected respective mice against a number of murine models of human diseases, including rheumatoid arthritis, psoriasis, and multiple sclerosis [113].

\section{Conclusions and Future Directions}

TTP has been extensively studied with respect to its role in inflammation and has long been assumed to be an exclusively anti-inflammatory factor, based both on the severe inflammatory phenotype of the respective knockout mice and its wealth of inflammatory targets. Nevertheless, in the meantime, it has been acknowledged that its function is not quite that unambiguous as TTP also attenuates the expression of anti-inflammatory mediators. Considering its tight regulation throughout the course of inflammation and its broad spectrum of targets, TTP might rather be assigned as a master regulator of the resolution of inflammation ensuring a well-coordinated and timely return to homeostasis after an inflammatory insult.

Consequently, modulating TTP might provide a promising avenue for the development of inflammation regulatory therapies. Specifically, therapeutic approaches to increase the TTP activity can be expected to ameliorate the course of numerous chronic inflammatory diseases with a previously shown connection to TTP, such as rheumatoid arthritis $[108,114,115]$, atherosclerosis [116], diabetes [117], inflammatory bowel disease [118], chronic obstructive pulmonary disease [119], and autoimmune diseases [108,120]. Since chronic inflammatory diseases are a major health care burden, such approaches appear extremely appealing. For example, PP2A agonists were shown to activate TTP and consequently reduced inflammation and bone loss in a murine rheumatoid arthritis model [121]. Further, small molecules could be screened for their potential to enhance TTP activity either by increasing its transcription or its mRNA stability or by preventing its inactivation. Nevertheless, such approaches commonly are limited by off-target effects. Considering the self-regulatory properties of TTP, the design of steric-blocking oligonucleotides to prevent the interaction of TTP with its own mRNA should enhance TTP expression [122]. In contrast, TTP-inhibitory approaches should intensify and prolong inflammatory processes and therefore are predicted to favor acute anti-bacterial reactions [107]. Nevertheless, considering the important function of TTP in the resolution of inflammation, TTP-inhibitory anti-infectious therapies should be developed with caution. Irrespective of the direction, potential therapeutic endeavors will have to factor in the cell type-specificity of TTP targets and the so far largely neglected interplay between TTP and other trans-acting regulators including RBPs and miRNAs.

It will further be of great interest to see if polymorphisms in TTP exist in humans, which might serve as markers for the individual susceptibility to certain chronic inflammatory diseases.

Author Contributions: Writing-original draft preparation, P.R. and T.S.; writing—review and editing, B.B. and T.S. All authors have read and agreed to the published version of the manuscript.

Funding: This work was supported by grants of the DFG (GRK 2336 TP6, SCHM2663/7).

Conflicts of Interest: The authors declare no conflict of interest. 


\section{References}

1. Hao, S.; Baltimore, D. The stability of mRNA influences the temporal order of the induction of genes encoding inflammatory molecules. Nat. Immunol. 2009, 10, 281-288. [CrossRef] [PubMed]

2. Anderson, P. Post-transcriptional regulons coordinate the initiation and resolution of inflammation. Nat. Rev. Immunol. 2010, 10, 24-35. [CrossRef] [PubMed]

3. Segal, A.W.; Peters, T.J. Characterisation of the enzyme defect in chronic granulomatous disease. Lancet 1976, 1, 1363-1365. [CrossRef]

4. Bradford, K.L.; Moretti, F.A.; Carbonaro-Sarracino, D.A.; Gaspar, H.B.; Kohn, D.B. Adenosine Deaminase (ADA)-Deficient Severe Combined Immune Deficiency (SCID): Molecular Pathogenesis and Clinical Manifestations. J. Clin. Immunol. $2017,37,626-637$. [CrossRef]

5. Brüne, B.; Dehne, N.; Grossmann, N.; Jung, M.; Namgaladze, D.; Schmid, T.; von Knethen, A.; Weigert, A. Redox control of inflammation in macrophages. Antioxid. Redox Signal. 2013, 19, 595-637. [CrossRef] [PubMed]

6. Gilroy, D.; de Maeyer, R. New insights into the resolution of inflammation. Semin. Immunol. 2015, 27, 161-168. [CrossRef]

7. Ibrahim, Z.A.; Armour, C.L.; Phipps, S.; Sukkar, M.B. RAGE and TLRs: Relatives, friends or neighbours? Mol. Immunol. 2013, 56, 739-744. [CrossRef]

8. Zhang, X.; Mosser, D.M. Macrophage activation by endogenous danger signals. J. Pathol. 2008, 214, 161-178. [CrossRef]

9. Gong, T.; Liu, L.; Jiang, W.; Zhou, R. DAMP-sensing receptors in sterile inflammation and inflammatory diseases. Nat. Rev. Immunol. 2020, 20, 95-112. [CrossRef]

10. Schaefer, L. Complexity of danger: The diverse nature of damage-associated molecular patterns. J. Biol. Chem. 2014, 289, 3523735245. [CrossRef]

11. Qian, C.; Cao, X. Regulation of Toll-like receptor signaling pathways in innate immune responses. Ann. N. Y. Acad. Sci. 2013, 1283, 67-74. [CrossRef] [PubMed]

12. Adelaja, A.; Hoffmann, A. Signaling Crosstalk Mechanisms That May Fine-Tune Pathogen-Responsive NFkB. Front. Immunol. 2019, 10, 433. [CrossRef] [PubMed]

13. Kienle, K.; Lämmermann, T. Neutrophil swarming: An essential process of the neutrophil tissue response. Immunol. Rev. 2016, 273, 76-93. [CrossRef] [PubMed]

14. Uderhardt, S.; Martins, A.J.; Tsang, J.S.; Lämmermann, T.; Germain, R.N. Resident Macrophages Cloak Tissue Microlesions to Prevent Neutrophil-Driven Inflammatory Damage. Cell 2019, 177, 541-555.e17. [CrossRef] [PubMed]

15. Prame Kumar, K.; Nicholls, A.J.; Wong, C.H.Y. Partners in crime: Neutrophils and monocytes/macrophages in inflammation and disease. Cell Tissue Res. 2018, 371, 551-565. [CrossRef]

16. Shi, C.; Pamer, E.G. Monocyte recruitment during infection and inflammation. Nat. Rev. Immunol. 2011, 11, 762-774. [CrossRef]

17. Mantovani, A.; Biswas, S.K.; Galdiero, M.R.; Sica, A.; Locati, M. Macrophage plasticity and polarization in tissue repair and remodelling. J. Pathol. 2013, 229, 176-185. [CrossRef]

18. Fujiwara, N.; Kobayashi, K. Macrophages in inflammation. Curr. Drug Targets Inflamm. Allergy 2005, 4, 281-286. [CrossRef]

19. Xue, J.; Schmidt, S.V.; Sander, J.; Draffehn, A.; Krebs, W.; Quester, I.; de Nardo, D.; Gohel, T.D.; Emde, M.; Schmidleithner, L.; et al. Transcriptome-based network analysis reveals a spectrum model of human macrophage activation. Immunity 2014, 40, 274-288. [CrossRef]

20. Zhang, S.; Weinberg, S.; DeBerge, M.; Gainullina, A.; Schipma, M.; Kinchen, J.M.; Ben-Sahra, I.; Gius, D.R.; Yvan-Charvet, L.; Chandel, N.S.; et al. Efferocytosis Fuels Requirements of Fatty Acid Oxidation and the Electron Transport Chain to Polarize Macrophages for Tissue Repair. Cell Metab. 2019, 29, 443-456.e5. [CrossRef]

21. Fadok, V.A.; Bratton, D.L.; Konowal, A.; Freed, P.W.; Westcott, J.Y.; Henson, P.M. Macrophages that have ingested apoptotic cells in vitro inhibit proinflammatory cytokine production through autocrine/paracrine mechanisms involving TGF-beta, PGE2, and PAF. J. Clin. Investig. 1998, 101, 890-898. [CrossRef] [PubMed]

22. Kourtzelis, I.; Hajishengallis, G.; Chavakis, T. Phagocytosis of Apoptotic Cells in Resolution of Inflammation. Front. Immunol. 2020, 11, 553. [CrossRef] [PubMed]

23. Stables, M.J.; Shah, S.; Camon, E.B.; Lovering, R.C.; Newson, J.; Bystrom, J.; Farrow, S.; Gilroy, D.W. Transcriptomic analyses of murine resolution-phase macrophages. Blood 2011, 118, e192-e208. [CrossRef]

24. Buckley, C.D.; Gilroy, D.W.; Serhan, C.N. Proresolving lipid mediators and mechanisms in the resolution of acute inflammation. Immunity 2014, 40, 315-327. [CrossRef] [PubMed]

25. Serhan, C.N.; Chiang, N.; van Dyke, T.E. Resolving inflammation: Dual anti-inflammatory and pro-resolution lipid mediators. Nat. Rev. Immunol. 2008, 8, 349-361. [CrossRef] [PubMed]

26. Levy, B.D.; Clish, C.B.; Schmidt, B.; Gronert, K.; Serhan, C.N. Lipid mediator class switching during acute inflammation: Signals in resolution. Nat. Immunol. 2001, 2, 612-619. [CrossRef]

27. Serhan, C.N.; Savill, J. Resolution of inflammation: The beginning programs the end. Nat. Immunol. 2005, 6, 1191-1197. [CrossRef]

28. Feehan, K.T.; Gilroy, D.W. Is Resolution the End of Inflammation? Trends Mol. Med. 2019, 25, 198-214. [CrossRef]

29. Newson, J.; Motwani, M.P.; Kendall, A.C.; Nicolaou, A.; Muccioli, G.G.; Alhouayek, M.; Bennett, M.; van de Merwe, R.; James, S.; Maeyer, R.P.H.; et al. Inflammatory Resolution Triggers a Prolonged Phase of Immune Suppression through COX-1/mPGES-1Derived Prostaglandin E2. Cell Rep. 2017, 20, 3162-3175. [CrossRef] 
30. Gautier, E.L.; Ivanov, S.; Lesnik, P.; Randolph, G.J. Local apoptosis mediates clearance of macrophages from resolving inflammation in mice. Blood 2013, 122, 2714-2722. [CrossRef]

31. Liu, Z.; Gu, Y.; Chakarov, S.; Bleriot, C.; Kwok, I.; Chen, X.; Shin, A.; Huang, W.; Dress, R.J.; Dutertre, C.-A.; et al. Fate Mapping via Ms4a3-Expression History Traces Monocyte-Derived Cells. Cell 2019, 178, 1509-1525.e19. [CrossRef] [PubMed]

32. Chakarov, S.; Lim, H.Y.; Tan, L.; Lim, S.Y.; See, P.; Lum, J.; Zhang, X.-M.; Foo, S.; Nakamizo, S.; Duan, K.; et al. Two distinct interstitial macrophage populations coexist across tissues in specific subtissular niches. Science 2019, 363. [CrossRef] [PubMed]

33. Lawrence, T. The nuclear factor NF-kappaB pathway in inflammation. Cold Spring Harb. Perspect. Biol. 2009, 1, a001651. [CrossRef] [PubMed]

34. Kaplan, M.H. STAT signaling in inflammation. Jakstat 2013, 2, e24198. [CrossRef] [PubMed]

35. Lawrence, T.; Fong, C. The resolution of inflammation: Anti-inflammatory roles for NF-kappaB. Int. J. Biochem. Cell Biol. 2010, 42, 519-523. [CrossRef]

36. Panni, S.; Lovering, R.C.; Porras, P.; Orchard, S. Non-coding RNA regulatory networks. Biochim. Biophys. Acta Gene Regul. Mech. 2020, 1863, 194417. [CrossRef]

37. Tiedje, C.; Diaz-Muñoz, M.D.; Trulley, P.; Ahlfors, H.; Laaß, K.; Blackshear, P.J.; Turner, M.; Gaestel, M. The RNA-binding protein TTP is a global post-transcriptional regulator of feedback control in inflammation. Nucleic Acids Res. 2016, 44, 7418-7440. [CrossRef]

38. Harvey, R.F.; Smith, T.S.; Mulroney, T.; Queiroz, R.M.L.; Pizzinga, M.; Dezi, V.; Villenueva, E.; Ramakrishna, M.; Lilley, K.S.; Willis, A.E. Trans-acting translational regulatory RNA binding proteins. Wiley Interdiscip. Rev. RNA 2018, 9, e1465. [CrossRef]

39. Mino, T.; Takeuchi, O. Regnase-1 and Roquin regulate inflammatory mRNAs. Oncotarget 2015, 6, 17869-17870. [CrossRef]

40. Blazusiak, E.; Florczyk, D.; Jura, J.; Potempa, J.; Koziel, J. Differential regulation by Toll-like receptor agonists reveals that MCPIP1 is the potent regulator of innate immunity in bacterial and viral infections. J. Innate Immun. 2013, 5, 15-23. [CrossRef]

41. Fu, M.; Blackshear, P.J. RNA-binding proteins in immune regulation: A focus on CCCH zinc finger proteins. Nat. Rev. Immunol. 2017, 17, 130-143. [CrossRef] [PubMed]

42. Li, Y.; Huang, X.; Huang, S.; He, H.; Lei, T.; Saaoud, F.; Yu, X.-Q.; Melnick, A.; Kumar, A.; Papasian, C.J.; et al. Central role of myeloid MCPIP1 in protecting against LPS-induced inflammation and lung injury. Signal Transduct. Target. 2017, 2, 17066. [CrossRef] [PubMed]

43. Mao, R.; Yang, R.; Chen, X.; Harhaj, E.W.; Wang, X.; Fan, Y. Regnase-1, a rapid response ribonuclease regulating inflammation and stress responses. Cell. Mol. Immunol. 2017, 14, 412-422. [CrossRef] [PubMed]

44. Mino, T.; Iwai, N.; Endo, M.; Inoue, K.; Akaki, K.; Hia, F.; Uehata, T.; Emura, T.; Hidaka, K.; Suzuki, Y.; et al. Translation-dependent unwinding of stem-loops by UPF1 licenses Regnase-1 to degrade inflammatory mRNAs. Nucleic Acids Res. 2019, 47, 8838-8859. [CrossRef] [PubMed]

45. Miao, R.; Huang, S.; Zhou, Z.; Quinn, T.; van Treeck, B.; Nayyar, T.; Dim, D.; Jiang, Z.; Papasian, C.J.; Eugene Chen, Y.; et al. Targeted disruption of MCPIP1/Zc3h12a results in fatal inflammatory disease. Immunol. Cell Biol. 2013, 91, 368-376. [CrossRef] [PubMed]

46. Leppek, K.; Schott, J.; Reitter, S.; Poetz, F.; Hammond, M.C.; Stoecklin, G. Roquin promotes constitutive mRNA decay via a conserved class of stem-loop recognition motifs. Cell 2013, 153, 869-881. [CrossRef]

47. Mino, T.; Murakawa, Y.; Fukao, A.; Vandenbon, A.; Wessels, H.-H.; Ori, D.; Uehata, T.; Tartey, S.; Akira, S.; Suzuki, Y.; et al. Regnase-1 and Roquin Regulate a Common Element in Inflammatory mRNAs by Spatiotemporally Distinct Mechanisms. Cell 2015, 161, 1058-1073. [CrossRef]

48. Tavernier, S.J.; Athanasopoulos, V.; Verloo, P.; Behrens, G.; Staal, J.; Bogaert, D.J.; Naesens, L.; de Bruyne, M.; van Gassen, S.; Parthoens, E.; et al. A human immune dysregulation syndrome characterized by severe hyperinflammation with a homozygous nonsense Roquin-1 mutation. Nat. Commun. 2019, 10, 4779. [CrossRef]

49. Castello, A.; Hentze, M.W.; Preiss, T. Metabolic Enzymes Enjoying New Partnerships as RNA-Binding Proteins. Trends Endocrinol. Metab. 2015, 26, 746-757. [CrossRef]

50. Balcerak, A.; Trebinska-Stryjewska, A.; Konopinski, R.; Wakula, M.; Grzybowska, E.A. RNA-protein interactions: Disorder, moonlighting and junk contribute to eukaryotic complexity. Open Biol. 2019, 9, 190096. [CrossRef]

51. Fukuzumi, M.; Shinomiya, H.; Shimizu, Y.; Ohishi, K.; Utsumi, S. Endotoxin-induced enhancement of glucose influx into murine peritoneal macrophages via GLUT1. Infect. Immun. 1996, 64, 108-112. [CrossRef]

52. Wang, H.; Ye, J. Regulation of energy balance by inflammation: Common theme in physiology and pathology. Rev. Endocr. Metab. Disord. 2015, 16, 47-54. [CrossRef] [PubMed]

53. Taylor, G.A.; Lai, W.S.; Oakey, R.J.; Seldin, M.F.; Shows, T.B.; Eddy, R.L.; Blackshear, P.J. The human TTP protein: Sequence, alignment with related proteins, and chromosomal localization of the mouse and human genes. Nucleic Acids Res. 1991, $19,3454$. [CrossRef] [PubMed]

54. Wells, M.L.; Perera, L.; Blackshear, P.J. An Ancient Family of RNA-Binding Proteins: Still Important! Trends Biochem. Sci. 2017, 42, 285-296. [CrossRef] [PubMed]

55. Brook, M.; Tchen, C.R.; Santalucia, T.; McIlrath, J.; Arthur, J.S.C.; Saklatvala, J.; Clark, A.R. Posttranslational regulation of tristetraprolin subcellular localization and protein stability by p38 mitogen-activated protein kinase and extracellular signalregulated kinase pathways. Mol. Cell. Biol. 2006, 26, 2408-2418. [CrossRef] [PubMed] 
56. Marderosian, M.; Sharma, A.; Funk, A.P.; Vartanian, R.; Masri, J.; Jo, O.D.; Gera, J.F. Tristetraprolin regulates Cyclin D1 and c-Myc mRNA stability in response to rapamycin in an Akt-dependent manner via p38 MAPK signaling. Oncogene 2006, 25, 6277-6290. [CrossRef]

57. Ronkina, N.; Shushakova, N.; Tiedje, C.; Yakovleva, T.; Tollenaere, M.A.X.; Scott, A.; Batth, T.S.; Olsen, J.V.; Helmke, A.; Bekker-Jensen, S.H.; et al. The Role of TTP Phosphorylation in the Regulation of Inflammatory Cytokine Production by MK2/3. J. Immunol. 2019, 203, 2291-2300. [CrossRef]

58. Rezcallah, M.C.; Al-Mazi, T.; Ammit, A.J. Cataloguing the phosphorylation sites of tristetraprolin (TTP): Functional implications for inflammatory diseases. Cell. Signal. 2020, 109868. [CrossRef]

59. Hitti, E.; Iakovleva, T.; Brook, M.; Deppenmeier, S.; Gruber, A.D.; Radzioch, D.; Clark, A.R.; Blackshear, P.J.; Kotlyarov, A.; Gaestel, M. Mitogen-activated protein kinase-activated protein kinase 2 regulates tumor necrosis factor mRNA stability and translation mainly by altering tristetraprolin expression, stability, and binding to adenine/uridine-rich element. Mol. Cell. Biol. 2006, 26, 2399-2407. [CrossRef]

60. O'Neil, J.D.; Ammit, A.J.; Clark, A.R. MAPK p38 regulates inflammatory gene expression via tristetraprolin: Doing good by stealth. Int. J. Biochem. Cell Biol. 2018, 94, 6-9. [CrossRef]

61. Chrestensen, C.A.; Schroeder, M.J.; Shabanowitz, J.; Hunt, D.F.; Pelo, J.W.; Worthington, M.T.; Sturgill, T.W. MAPKAP kinase 2 phosphorylates tristetraprolin on in vivo sites including Ser178, a site required for 14-3-3 binding. J. Biol. Chem. 2004, 279, 10176-10184. [CrossRef] [PubMed]

62. Stoecklin, G.; Stubbs, T.; Kedersha, N.; Wax, S.; Rigby, W.F.C.; Blackwell, T.K.; Anderson, P. MK2-induced tristetraprolin:14-3-3 complexes prevent stress granule association and ARE-mRNA decay. Embo J. 2004, 23, 1313-1324. [CrossRef] [PubMed]

63. Clark, A.R.; Dean, J.L.E. The control of inflammation via the phosphorylation and dephosphorylation of tristetraprolin: A tale of two phosphatases. Biochem. Soc. Trans. 2016, 44, 1321-1337. [CrossRef] [PubMed]

64. Shah, S.; King, E.M.; Mostafa, M.M.; Altonsy, M.O.; Newton, R. DUSP1 Maintains IRF1 and Leads to Increased Expression of IRF1dependent Genes: A MECHANISM PROMOTING GLUCOCORTICOID INSENSITIVITY. J. Biol. Chem. 2016, 291 , 21802-21816. [CrossRef]

65. Smallie, T.; Ross, E.A.; Ammit, A.J.; Cunliffe, H.E.; Tang, T.; Rosner, D.R.; Ridley, M.L.; Buckley, C.D.; Saklatvala, J.; Dean, J.L.; et al. Dual-Specificity Phosphatase 1 and Tristetraprolin Cooperate To Regulate Macrophage Responses to Lipopolysaccharide. J. Immunol. 2015, 195, 277-288. [CrossRef]

66. Sun, L.; Stoecklin, G.; van Way, S.; Hinkovska-Galcheva, V.; Guo, R.-F.; Anderson, P.; Shanley, T.P. Tristetraprolin (TTP)-14-3-3 complex formation protects TTP from dephosphorylation by protein phosphatase $2 \mathrm{a}$ and stabilizes tumor necrosis factor-alpha mRNA. J. Biol. Chem. 2007, 282, 3766-3777. [CrossRef]

67. Rahman, M.M.; Rumzhum, N.N.; Hansbro, P.M.; Morris, J.C.; Clark, A.R.; Verrills, N.M.; Ammit, A.J. Activating protein phosphatase 2A (PP2A) enhances tristetraprolin (TTP) anti-inflammatory function in A549 lung epithelial cells. Cell. Signal. 2016, 28, 325-334. [CrossRef]

68. Tang, T.; Scambler, T.E.; Smallie, T.; Cunliffe, H.E.; Ross, E.A.; Rosner, D.R.; O'Neil, J.D.; Clark, A.R. Macrophage responses to lipopolysaccharide are modulated by a feedback loop involving prostaglandin E2, dual specificity phosphatase 1 and tristetraprolin. Sci. Rep. 2017, 7, 4350. [CrossRef]

69. Brewer, B.Y.; Malicka, J.; Blackshear, P.J.; Wilson, G.M. RNA sequence elements required for high affinity binding by the zinc finger domain of tristetraprolin: Conformational changes coupled to the bipartite nature of Au-rich MRNA-destabilizing motifs. J. Biol. Chem. 2004, 279, 27870-27877. [CrossRef]

70. Zubiaga, A.M.; Belasco, J.G.; Greenberg, M.E. The nonamer UUAUUUAUU is the key AU-rich sequence motif that mediates mRNA degradation. Mol. Cell. Biol. 1995, 15, 2219-2230. [CrossRef]

71. Fallmann, J.; Sedlyarov, V.; Tanzer, A.; Kovarik, P.; Hofacker, I.L. AREsite2: An enhanced database for the comprehensive investigation of AU/GU/U-rich elements. Nucleic Acids Res. 2016, 44, D90-5. [CrossRef] [PubMed]

72. Lai, W.S.; Carballo, E.; Strum, J.R.; Kennington, E.A.; Phillips, R.S.; Blackshear, P.J. Evidence that tristetraprolin binds to AU-rich elements and promotes the deadenylation and destabilization of tumor necrosis factor alpha mRNA. Mol. Cell. Biol. 1999, 19, 4311-4323. [CrossRef] [PubMed]

73. Worthington, M.T.; Pelo, J.W.; Sachedina, M.A.; Applegate, J.L.; Arseneau, K.O.; Pizarro, T.T. RNA binding properties of the AU-rich element-binding recombinant Nup475/TIS11/tristetraprolin protein. J. Biol. Chem. 2002, 277, 48558-48564. [CrossRef] [PubMed]

74. Sedlyarov, V.; Fallmann, J.; Ebner, F.; Huemer, J.; Sneezum, L.; Ivin, M.; Kreiner, K.; Tanzer, A.; Vogl, C.; Hofacker, I.; et al. Tristetraprolin binding site atlas in the macrophage transcriptome reveals a switch for inflammation resolution. Mol. Syst. Biol. 2016, 12, 868. [CrossRef]

75. Kratochvill, F.; Machacek, C.; Vogl, C.; Ebner, F.; Sedlyarov, V.; Gruber, A.R.; Hartweger, H.; Vielnascher, R.; Karaghiosoff, M.; Rülicke, T.; et al. Tristetraprolin-driven regulatory circuit controls quality and timing of mRNA decay in inflammation. Mol. Syst. Biol. 2011, 7, 560. [CrossRef]

76. Mukherjee, N.; Jacobs, N.C.; Hafner, M.; Kennington, E.A.; Nusbaum, J.D.; Tuschl, T.; Blackshear, P.J.; Ohler, U. Global target mRNA specification and regulation by the RNA-binding protein ZFP36. Genome Biol. 2014, 15, R12. [CrossRef]

77. Blackshear, P.J.; Perera, L. Phylogenetic distribution and evolution of the linked RNA-binding and NOT1-binding domains in the tristetraprolin family of tandem CCCH zinc finger proteins. J. Interferon Cytokine Res. 2014, 34, 297-306. [CrossRef] 
78. Clement, S.L.; Scheckel, C.; Stoecklin, G.; Lykke-Andersen, J. Phosphorylation of tristetraprolin by MK2 impairs AU-rich element mRNA decay by preventing deadenylase recruitment. Mol. Cell. Biol. 2011, 31, 256-266. [CrossRef]

79. Fabian, M.R.; Frank, F.; Rouya, C.; Siddiqui, N.; Lai, W.S.; Karetnikov, A.; Blackshear, P.J.; Nagar, B.; Sonenberg, N. Structural basis for the recruitment of the human CCR4-NOT deadenylase complex by tristetraprolin. Nat. Struct. Mol. Biol. 2013, 20, 735-739. [CrossRef]

80. Lykke-Andersen, J.; Wagner, E. Recruitment and activation of mRNA decay enzymes by two ARE-mediated decay activation domains in the proteins TTP and BRF-1. Genes Dev. 2005, 19, 351-361. [CrossRef]

81. Wahle, E.; Winkler, G.S. RNA decay machines: Deadenylation by the Ccr4-not and Pan2-Pan3 complexes. Biochim. Biophys. Acta 2013, 1829, 561-570. [CrossRef] [PubMed]

82. Tiedje, C.; Ronkina, N.; Tehrani, M.; Dhamija, S.; Laass, K.; Holtmann, H.; Kotlyarov, A.; Gaestel, M. The p38/MK2-driven exchange between tristetraprolin and HuR regulates AU-rich element-dependent translation. PLoS Genet. 2012, 8, e1002977. [CrossRef] [PubMed]

83. Zhang, X.; Chen, X.; Liu, Q.; Zhang, S.; Hu, W. Translation repression via modulation of the cytoplasmic poly(A)-binding protein in the inflammatory response. Elife 2017, 6. [CrossRef] [PubMed]

84. Schott, J.; Reitter, S.; Philipp, J.; Haneke, K.; Schäfer, H.; Stoecklin, G. Translational regulation of specific mRNAs controls feedback inhibition and survival during macrophage activation. PLoS Genet. 2014, 10, e1004368. [CrossRef]

85. Ostareck, D.H.; Ostareck-Lederer, A. RNA-Binding Proteins in the Control of LPS-Induced Macrophage Response. Front. Genet. 2019, 10, 31. [CrossRef]

86. Brooks, S.A.; Connolly, J.E.; Rigby, W.F.C. The role of mRNA turnover in the regulation of tristetraprolin expression: Evidence for an extracellular signal-regulated kinase-specific, AU-rich element-dependent, autoregulatory pathway. J. Immunol. 2004, 172, 7263-7271. [CrossRef]

87. Arlt, A.; Schäfer, H. Role of the immediate early response 3 (IER3) gene in cellular stress response, inflammation and tumorigenesis. Eur. J. Cell Biol. 2011, 90, 545-552. [CrossRef]

88. Connolly, B.M.; Choi, E.Y.; Gårdsvoll, H.; Bey, A.L.; Currie, B.M.; Chavakis, T.; Liu, S.; Molinolo, A.; Ploug, M.; Leppla, S.H.; et al. Selective abrogation of the uPA-uPAR interaction in vivo reveals a novel role in suppression of fibrin-associated inflammation. Blood 2010, 116, 1593-1603. [CrossRef]

89. Kanno, Y.; Ishisaki, A.; Kawashita, E.; Kuretake, H.; Ikeda, K.; Matsuo, O. uPA Attenuated LPS-induced Inflammatory Osteoclastogenesis through the Plasmin/PAR-1/Ca(2+)/CaMKK/AMPK Axis. Int. J. Biol. Sci. 2016, 12, 63-71. [CrossRef]

90. Mahmoud, L.; Moghrabi, W.; Khabar, K.S.A.; Hitti, E.G. Bi-phased regulation of the post-transcriptional inflammatory response by Tristetraprolin levels. RNA Biol. 2019, 16, 309-319. [CrossRef]

91. Datta, S.; Biswas, R.; Novotny, M.; Pavicic, P.G.; Herjan, T.; Mandal, P.; Hamilton, T.A. Tristetraprolin regulates CXCL1 (KC) mRNA stability. J. Immunol. 2008, 180, 2545-2552. [CrossRef]

92. Jalonen, U.; Nieminen, R.; Vuolteenaho, K.; Kankaanranta, H.; Moilanen, E. Down-regulation of tristetraprolin expression results in enhanced IL-12 and MIP-2 production and reduced MIP-3alpha synthesis in activated macrophages. Mediat. Inflamm. 2006, 2006, 40691. [CrossRef]

93. De Filippo, K.; Dudeck, A.; Hasenberg, M.; Nye, E.; van Rooijen, N.; Hartmann, K.; Gunzer, M.; Roers, A.; Hogg, N. Mast cell and macrophage chemokines CXCL1/CXCL2 control the early stage of neutrophil recruitment during tissue inflammation. Blood 2013, 121, 4930-4937. [CrossRef] [PubMed]

94. Sugimoto, M.A.; Sousa, L.P.; Pinho, V.; Perretti, M.; Teixeira, M.M. Resolution of Inflammation: What Controls Its Onset? Front. Immunol. 2016, 7, 160. [CrossRef] [PubMed]

95. Schaljo, B.; Kratochvill, F.; Gratz, N.; Sadzak, I.; Sauer, I.; Hammer, M.; Vogl, C.; Strobl, B.; Müller, M.; Blackshear, P.J.; et al. Tristetraprolin is required for full anti-inflammatory response of murine macrophages to IL-10. J. Immunol. 2009, 183, 1197-1206. [CrossRef] [PubMed]

96. Tudor, C.; Marchese, F.P.; Hitti, E.; Aubareda, A.; Rawlinson, L.; Gaestel, M.; Blackshear, P.J.; Clark, A.R.; Saklatvala, J.; Dean, J.L.E. The p38 MAPK pathway inhibits tristetraprolin-directed decay of interleukin-10 and pro-inflammatory mediator mRNAs in murine macrophages. Febs Lett. 2009, 583, 1933-1938. [CrossRef] [PubMed]

97. Stoecklin, G.; Tenenbaum, S.A.; Mayo, T.; Chittur, S.V.; George, A.D.; Baroni, T.E.; Blackshear, P.J.; Anderson, P. Genome-wide analysis identifies interleukin-10 mRNA as target of tristetraprolin. J. Biol. Chem. 2008, 283, 11689-11699. [CrossRef]

98. Sauer, I.; Schaljo, B.; Vogl, C.; Gattermeier, I.; Kolbe, T.; Müller, M.; Blackshear, P.J.; Kovarik, P. Interferons limit inflammatory responses by induction of tristetraprolin. Blood 2006, 107, 4790-4797. [CrossRef]

99. Kang, J.-G.; Amar, M.J.; Remaley, A.T.; Kwon, J.; Blackshear, P.J.; Wang, P.-y.; Hwang, P.M. Zinc finger protein tristetraprolin interacts with CCL3 mRNA and regulates tissue inflammation. J. Immunol. 2011, 187, 2696-2701. [CrossRef]

100. Mahmoud, L.; Abdulkarim, A.S.; Kutbi, S.; Moghrabi, W.; Altwijri, S.; Khabar, K.S.A.; Hitti, E.G. Post-Transcriptional Inflammatory Response to Intracellular Bacterial c-di-AMP. Front. Immunol. 2019, 10, 3050. [CrossRef]

101. Guan, E.; Wang, J.; Norcross, M.A. Identification of human macrophage inflammatory proteins 1alpha and 1beta as a native secreted heterodimer. J. Biol. Chem. 2001, 276, 12404-12409. [CrossRef] [PubMed]

102. Xu, L.L.; Warren, M.K.; Rose, W.L.; Gong, W.; Wang, J.M. Human recombinant monocyte chemotactic protein and other C-C chemokines bind and induce directional migration of dendritic cells in vitro. J. Leukoc. Biol. 1996, 60, 365-371. [CrossRef] [PubMed] 
103. Carballo, E.; Lai, W.S.; Blackshear, P.J. Feedback inhibition of macrophage tumor necrosis factor-alpha production by tristetraprolin. Science 1998, 281, 1001-1005. [CrossRef] [PubMed]

104. Kontoyiannis, D.; Kotlyarov, A.; Carballo, E.; Alexopoulou, L.; Blackshear, P.J.; Gaestel, M.; Davis, R.; Flavell, R.; Kollias, G. Interleukin-10 targets p38 MAPK to modulate ARE-dependent TNF mRNA translation and limit intestinal pathology. Embo J. 2001, 20, 3760-3770. [CrossRef]

105. Mahtani, K.R.; Brook, M.; Dean, J.L.; Sully, G.; Saklatvala, J.; Clark, A.R. Mitogen-activated protein kinase p38 controls the expression and posttranslational modification of tristetraprolin, a regulator of tumor necrosis factor alpha mRNA stability. Mol. Cell. Biol. 2001, 21, 6461-6469. [CrossRef]

106. Joe, Y.; Chen, Y.; Park, J.; Kim, H.J.; Rah, S.-Y.; Ryu, J.; Cho, G.J.; Choi, H.-S.; Ryter, S.W.; Park, J.W.; et al. Cross-talk between CD38 and TTP Is Essential for Resolution of Inflammation during Microbial Sepsis. Cell Rep. 2020, 30, 1063-1076.e5. [CrossRef]

107. Ebner, F.; Sedlyarov, V.; Tasciyan, S.; Ivin, M.; Kratochvill, F.; Gratz, N.; Kenner, L.; Villunger, A.; Sixt, M.; Kovarik, P. The RNAbinding protein tristetraprolin schedules apoptosis of pathogen-engaged neutrophils during bacterial infection. J. Clin. Investig. 2017, 127, 2051-2065. [CrossRef]

108. Taylor, G.A.; Carballo, E.; Lee, D.M.; Lai, W.S.; Thompson, M.J.; Patel, D.D.; Schenkman, D.I.; Gilkeson, G.S.; Broxmeyer, H.E.; Haynes, B.F.; et al. A Pathogenetic Role for TNF $\alpha$ in the Syndrome of Cachexia, Arthritis, and Autoimmunity Resulting from Tristetraprolin (TTP) Deficiency. Immunity 1996, 4, 445-454. [CrossRef]

109. Patial, S.; Blackshear, P.J. Tristetraprolin as a Therapeutic Target in Inflammatory Disease. Trends Pharm. Sci. 2016, 37, 811-821. [CrossRef]

110. Qiu, L.-Q.; Stumpo, D.J.; Blackshear, P.J. Myeloid-specific tristetraprolin deficiency in mice results in extreme lipopolysaccharide sensitivity in an otherwise minimal phenotype. J. Immunol. 2012, 188, 5150-5159. [CrossRef]

111. O’Neil, J.D.; Ross, E.A.; Ridley, M.L.; Ding, Q.; Tang, T.; Rosner, D.R.; Crowley, T.; Malhi, D.; Dean, J.L.; Smallie, T.; et al. Gain-of-Function Mutation of Tristetraprolin Impairs Negative Feedback Control of Macrophages In Vitro yet Has Overwhelmingly Anti-Inflammatory Consequences In Vivo. Mol. Cell. Biol. 2017, 37. [CrossRef] [PubMed]

112. Ross, E.A.; Smallie, T.; Ding, Q.; O’Neil, J.D.; Cunliffe, H.E.; Tang, T.; Rosner, D.R.; Klevernic, I.; Morrice, N.A.; Monaco, C.; et al. Dominant Suppression of Inflammation via Targeted Mutation of the mRNA Destabilizing Protein Tristetraprolin. J. Immunol. 2015, 195, 265-276. [CrossRef] [PubMed]

113. Patial, S.; Curtis, A.D.; Lai, W.S.; Stumpo, D.J.; Hill, G.D.; Flake, G.P.; Mannie, M.D.; Blackshear, P.J. Enhanced stability of tristetraprolin mRNA protects mice against immune-mediated inflammatory pathologies. Proc. Natl. Acad. Sci. USA 2016, 113, 1865-1870. [CrossRef] [PubMed]

114. Fabris, M.; Tolusso, B.; Di Poi, E.; Tomietto, P.; Sacco, S.; Gremese, E.; Ferraccioli, G. Mononuclear cell response to lipopolysaccharide in patients with rheumatoid arthritis: Relationship with tristetraprolin expression. J. Rheumatol. 2005, 32, 998-1005. [PubMed]

115. Yamasaki, S. Recent advances in the role of RNA-binding protein, tristetraprolin, in arthritis. Immunol. Med. 2018, 41, 98-102. [CrossRef] [PubMed]

116. Zhang, H.; Taylor, W.R.; Joseph, G.; Caracciolo, V.; Gonzales, D.M.; Sidell, N.; Seli, E.; Blackshear, P.J.; Kallen, C.B. mRNA-binding protein ZFP36 is expressed in atherosclerotic lesions and reduces inflammation in aortic endothelial cells. Arterioscler. Thromb. Vasc. Biol. 2013, 33, 1212-1220. [CrossRef]

117. Caracciolo, V.; Young, J.; Gonzales, D.; Ni, Y.; Flowers, S.J.; Summer, R.; Waldman, S.A.; Kim, J.K.; Jung, D.Y.; Noh, H.L.; et al. Myeloid-specific deletion of $\mathrm{Zfp} 36$ protects against insulin resistance and fatty liver in diet-induced obese mice. Am. J. Physiol. Endocrinol. Metab. 2018, 315, E676-E693. [CrossRef]

118. Di Silvestre, A.; Lucafò, M.; Pugnetti, L.; Bramuzzo, M.; Stocco, G.; Barbi, E.; Decorti, G. Role of tristetraprolin phosphorylation in paediatric patients with inflammatory bowel disease. World J. Gastroenterol. 2019, 25, 5918-5925. [CrossRef]

119. Nair, P.M.; Starkey, M.R.; Haw, T.J.; Liu, G.; Collison, A.M.; Mattes, J.; Wark, P.A.; Morris, J.C.; Verrills, N.M.; Clark, A.R.; et al. Enhancing tristetraprolin activity reduces the severity of cigarette smoke-induced experimental chronic obstructive pulmonary disease. Clin. Transl. Immunol. 2019, 8, e01084. [CrossRef]

120. Yoshinaga, M.; Takeuchi, O. RNA binding proteins in the control of autoimmune diseases. Immunol. Med. 2019, 42, 53-64. [CrossRef]

121. Ross, E.A.; Naylor, A.J.; O’Neil, J.D.; Crowley, T.; Ridley, M.L.; Crowe, J.; Smallie, T.; Tang, T.J.; Turner, J.D.; Norling, L.V.; et al. Treatment of inflammatory arthritis via targeting of tristetraprolin, a master regulator of pro-inflammatory gene expression. Ann. Rheum. Dis. 2017, 76, 612-619. [CrossRef] [PubMed]

122. Kole, R.; Krainer, A.R.; Altman, S. RNA therapeutics: Beyond RNA interference and antisense oligonucleotides. Nat. Rev. Drug Discov. 2012, 11, 125-140. [CrossRef] [PubMed] 